\title{
ICHNOFOSILIE MYSLEJOVICKÉHO SOUVRSTVÍ DRAHANSKÉHO KULMU (SPODNÍ KARBON, MORAVSKOSLEZSKÁ JEDNOTKA ČESKÉHO MASIVU)
}

\author{
Trace fossils from the Myslejovice Formation of the Drahany Culm Basin (Lower \\ Carboniferous, Moravosilesian unit of the Bohemian Massif)
}

\author{
Martin Kováček', Tomáš Lehotský2, 3 \\ 1 Ústav geologických věd, Př́rodovědecká fakulta, Masarykova Univerzita, Kotlářská 267/2, 61137 Brno; \\ e-mail:380089@mail.muni.cz \\ ${ }^{2}$ Katedra geologie, Přírodovědecká fakulta Univerzity Palackého, 17. listopadu 12, 77146 Olomouc \\ ${ }^{3}$ Vlastivědné muzeum v Olomouci, nám. Republiky 5, 77173 Olomouc; e-mail: lehotsky@prfnw.upol.cz
}

$(24-41$ Vyškov)

Key words: Bohemian Massif, Moravosilesian Unit, Myslejovice Formation, Lower Carboniferous, Drahany Upland, Trace Fossils, associations

\begin{abstract}
The research in this study is focused on trace fossils of the Myslejovice Formation, which is one of the lithostratigraphical units in the Lower Carboniferous sequences of the Drahany Culm Basin that belongs to the large area of Rhenohercynian Zone of the Variscan orogenetic flysch belt. Ichnofossils have mainly been collected in the southeastern part, near Vyškov. The material comes from the collection of Mr. Veleslav Lang which is nowadays stored in the Regional Museum of Olomouc. From this collection total 615 specimens in 10 ichnogenera and 13 following ichnospecies were determined and redefined: ?Alcyonidiopsis isp., Cosmorhaphe isp., Dictyodora liebeana, Diplocraterion parallelum, Gordia isp., Chondrites $c f$. intricatus, Chondrites isp., Nereites missouriensis, Nereites isp., Phycosiphon incertum, Planolites beverleyensis, Planolites isp. and Rhizocorallium isp. The revised material comes from the following locations: Opatovice, Habrovany, Hamiltony, Ježkovice, Lhota, Luleč, Myslejovice, Nemojany - Blatická dolina, Nemojany, Otaslavice, Pístovice, Radslavice and Rychtáŕov. The overall character of ichnoassemblages indicates conditions of Nereites ichnofacies, which is typical for the distal parts of the suprafan turbidite lobes. Compared to other areas of Culm facies in Middle Europe, assemblages of the Myslejovice Formation belong among the less diversified.
\end{abstract}

\section{Úvod}

Již od konce 19. století byly sedimenty zejména v jihovýchodní části Drahanské vrchoviny zkoumány ze sedimentologického, strukturního i paleontologického hlediska. Především v posledním jmenovaném oboru přispěl významně svým podílem pedagog a sběratel zkamenělin Veleslav Lang. Svou rozsáhlou kolekci fosilií začal sestavovat již v roce 1939. Dnes je největší část jeho sbírky uložena v depozitáři Vlastivědného muzea v Olomouci. Spodnokarbonské fosilie, které V. Lang sbíral na lokalitách v myslejovickém souvrství, představují svým mimořádným počtem dostatečně reprezentativní soubor z jednotlivých lokalit a lze je tak využít ke stratigrafickým a paleoekologickým účelům. Významnou část sbírky tvoří fosilní stopy, které díky své autochtonní vazbě na prostředí poskytují možnost paleoekologických interpretací prostředí. Výzkum fosilních stop významně pokročil a v současnosti vznikla potřeba jednotlivé ichnodruhy $\mathrm{z}$ těchto lokalit nově revidovat.

Studované exempláře pocházejí z lokalit $\mathrm{v}$ jihovýchodní části myslejovického souvrství Drahanské vrchoviny (více např. Zita 1963; Lang 1973). Regionálně-geologicky spadá oblast do moravskoslezské jednotky Českého masivu a její převážná část je tvořena horninami kulmské facie, které byly uloženy v intervalu sp. visé-sp. namur. $\mathrm{V}$ protivanovském (sp.-stř. visé) a rozstáňském (sp.-sv. visé) souvrství jsou nálezy fosilních stop vzácné. Myslejovické souvrství je stratigraficky nejmladší (sv. visé-sp. namur) a zároveň reprezentuje nejúplnější sled horninových facií v kulmském vývoji Drahanské vrchoviny tvořený faciemi kosiŕských drob, studnických břidlic, račických a lulečských slepenců (Dvořák 1966). Na základě goniatitové zonace podle Kumpery a Langa (1975) je možné jednotlivé lokality stratigraficky zařadit do intervalu zón Goa-Goy.

\section{Metodika}

Studovaný materiál pochází ze sbírek Vlastivědného muzea v Olomouci. Z kolekce V. Langa bylo zpracováno 615 kusů. Exempláře pocházejí z lokalit v blízkém okolí obcí Opatovice, Pístovice, Ježkovice, Rychtářov, Radslavice, Hamiltony, Lhota, Nemojany, Olšany a Račice (obr. 1). V této práci je materiál řazen na základě alfabetického uspořádání v souhlasu a pracemi Häntzschela (1975), Seilachera (1992) a dalšími. Stopy jsou zachovány především v jemnozrnných členech souvrství - jílovcích, prachovcích až jemnozrnných drobách. To mnohdy negativně ovlivňuje morfologii stop a jejich kontrast vưči okolní hornině. Stopy nebývají postiženy kliváží a zvláště obytné struktury jsou zachovány relativně dobře.

\section{Systematická část}

Ichnorod Alcyonidiopsis Massalongo 1856

?Alcyonidiopsis isp.

Obr. 2a.

Materiál: 31 exemplářů.

Popis: Paprsčitě větvící se stopy, které nemají stejnou délku jednotlivých větví. Šířka jednotlivých větví se pohy- 


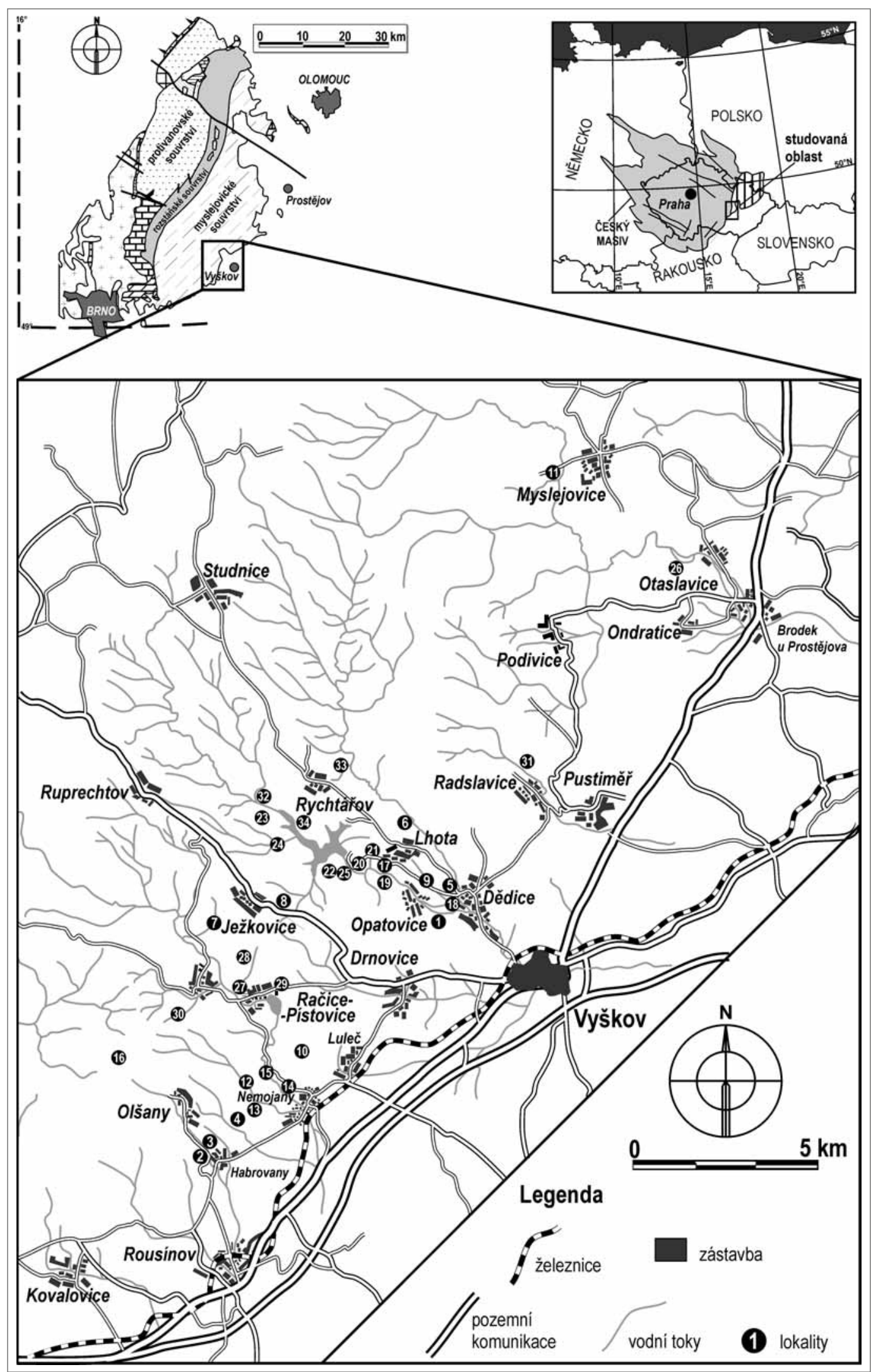

Obr. 1: Mapa lokalit s výskytem fosilních stop v kulmu jihovýchodní části Drahanské vrchoviny (lokality a jejich pozice upraveny podle Langa 1973). 1 - Dědice K (= Opatovice 3); 2 - Habrovany; 3 - Habrovany 1; 4 - Habrovany Bl. D.; 5 - Hamiltony; 6 - Hamiltony 1; 7 - Ježkovice K; 8 - Ježkovice R; 9 - Lhota 1; 10 - Luleč; 11 - Myslejovice; 12 - Nemojany Bl. D.; 13 - Nemojany H; 14 - Nemojany Ch; 15 - Nemojany I; 16 - Olšany; 17 - Opatovice 1; 18 - Opatovice 2; 19 - Opatovice 4; 20 - Opatovice 5; 21 - Opatovice 6; 22 - Opatovice 7; 23 - Opatovice 8; 24 - Opatovice 9; 25 - Opatovice 10;26 - Otaslavice; 27 - Pístovice Š; 28 - Pístovice Š1; 29 - Pístovice Ž; 30 - Račice; 31 - Radslavice; 32 - Rychtářov 1; 33 - Rychtáŕov 2; 34 - Rychtářov 3.

Fig. 1: Map of sites with occurence of trace fossils in the culm of the Southeastern part of the Drahany Upland (locations and their position according to Lang 1973). 
buje v intervalu 1,5-8,0 mm. V sagitálním průběhu jsou přímé, přičně zvlněné. Povrch stopy je tvořen $\mathrm{z}$ drobných granulí (? pelet) eliptického až kruhovitého obrysu. Celkový habitus stopy je plochý.

Poznámky: Uchman (1995) uvádí původní název Granularia drahana sp. n. Lang-Pek-Zapletal 1979 jako částečně př́slušný názvu Alcyonidiopsis Massalongo 1856. Diagnóza podle Chamberlaina (1977): jednoduché, vzácně se větvící tubulární chodby vyplněné fekálními peletami. Lang et al. (1979) patrně přisoudili stopě název na základě diagnózy stopy Granularia lumbricoides Rothpletz 1896, kterou později revidovala Fu (1991). Nicméně podle Uchmana (1995) se jedná o totéž synonymum stop Halymenites, Syncoprulus, Tomaculum a Phymatoderma granulatum. Tyto stopy jsou rovněž charakteristické vyplněním fekálními peletami, ale stále odráží větvící se strukturu.

Výskyt: Opatovice 6.

Ichnorod Cosmorhaphe Fuchs, 1895

Cosmorhaphe isp.

Obr. 2b.

Materiál: 25 exemplářů.

Popis: Nerozvětvené, hladké, páskované a horizontálně meandrující stopy. Vykazují zpravidla dva řády meandrů. Maximální šiŕka stopy je 3,5 mm.

Poznámky: Přestože není povětšinou zachován kompletní průběh stopy, lze přiřadit příslušnost materiálu k ichnorodu Cosmorhaphe např. srovnáním s ostatními ichnodruhy tohoto ichnorodu. Mikuláš et al. (2004) se domnívají, že v mnoha případech se jedná o bazální nebo horizontální ćásti meandrujícího systému stopy ichnorodu Dictyodora. Také Uchman (1998) vylučuje Cosmorhaphe timida Pfeiffer a Cosmorhaphe kettneri z ichnorodu Cosmorhaphe a přiklání se k výše zmíněnému názoru, že se jedná o části stopy ichnorodu Dictyodora. Stratigrafické rozpětí ichnorodu Cosmorhaphe je kambrium až recent (Ekdale a Berger 1978). Část typového materiálu Langa et al. (1979) určený jako Cosmorhaphe dvoraki n. sp. redefinujeme jako Cosmorhaphe isp.

Výskyt: Hamiltony 1 a 2, Opatovice 2, Opatovice 3, Opatovice 4, Opatovice 6, Opatovice 10, Nemojany Ch, Nemojany I, Pístovice Ž, Pístovice Š, Pístovice K, Vranovice.

Ichnorod Diplocraterion Torell, 1870

Diplocraterion parallelum Torell, 1870

Obr. 2c.

Materiál: 204 exemplářu doupat, trubic, sagitálních průřezů a nábrusů.

Popis: Vertikální stopy tvaru písmene „U“. V transverzálním řezu (šírka 4,0-25 mm) jsou trubice kruhovitého obrysu, postranní ramena jsou vůči sobě víceméně paralelní. Výjimečně mohou být ramena nestejnoměrně široká, jejich vzdálenost je individuální, pohybuje se v intervalu 4-10 mm. Ústí je jednoduché, u obou ramen utvářeno stejně.

Poznámky: Výplň stopy je tvořena jemnozrnnou přepracovanou drobou až prachovcem. Poloha stop v sedimentu je vůči vrstvám vždy vertikální. Lang et al. (1979) tento druh určili jako Arenicolites isp., který vykazuje podobnou morfologii. Pro kompletní synonymiku viz Fürsich (1974).

Výskyt: Pístovice Š, Pístovice Ž, Pístovice K, Rychtářov, Opatovice 1, Opatovice 2, Opatovice 3, Opatovice 4, Opatovice 6, Opatovice 8, Opatovice 9, Nemojany P, Nemojany H, Nemojany Blatnická Dolina, Hamiltony 1, Habrovany, Rychtářov.

Ichnorod Dictyodora Weiss, 1884

Dictyodora liebeana (Geinitz, 1867)

Obr. 2d.

Materiál: 171 exemplářò.

Popis: Základním charakteristickým rysem této stopy v horizontálním průřezu jsou spirální formy a dále formy meandrující (pravidelně i nepravidelně) či zcela nepravidelné typy. Transverzální rozměr stopy je 1,0-1,2 mm.

Poznámky: Pro detailní synonymiku odkazujeme na práci Bentona (1982). Komplikovaná třídimenzionální stavba stopy je důvodem velké morfologické variability na povrchu vrstev. Původcem stopy je komplexní endobiontní požírač substrátu (Stepanek a Geyer 1989).

Výskyt: Habrovany, Hamiltony 1, Ježkovice R, Kobylničky, Lhota 1, Myslejovice, Nemojany H, Nemojany I, Opatovice 2, Opatovice 3, Opatovice 4, Opatovice 6, Opatovice 8, Opatovice 10, Otaslavice, Pístovice K, Pístovice Š, Pístovice Ž, Podivice, Radslavice, Rychtářov, Vranovice.

\section{Ichnorod Gordia Emmons, 1844}

Gordia isp.

Obr. 2e.

Materiál: 65 exemplářò.

Popis: Nevětvené, nepravidelně a horizontálně meandrující stopy, které vytvářejí náhodné smyčky. Stopa je obvykle zachována v hypichniálním semireliéfu. Šírka stopy dosahuje maximálně $3,5 \mathrm{~mm}$. Na některých exemplářích ze sbírky V. Langa je patrná sagitální linie probíhající středem a paralelně orientovaná mediální struktura probíhající paralelně s vnějšími okraji.

Poznámky: Taxonomickou problematiku ichnorodu detailně řešili ve své práci napřr. Fillion a Pickerill (1990) či Pickerill a Peel (1991). Ichnorod Gordia vykazuje podobné znaky se stopami ichnorodu Helminthoidichnites, který však vytvárí smyčky pouze př́ležitostně, narozdíl od typického ichnodruhu Gordia marina Emmons, 1844 (Uchman 1998; Gaigalas a Uchman 2004). Podle Pickerilla et al. (1984) se jedná o faciálně přechodnou stopu známou jak z mořského, tak i z terestrického (lakustrinního) prostředí. V této práci je nový druh Cosmorhaphe dvoraki popisovaný Langem et al. (1979) uváděn jako sporný název a jejich typový materiál řadíme do ichnorodu Gordia na základě velmi častých smyčkovitých forem, které Lang et al. (opus cit.) neberou v potaz. Možná je však i př́ibuznost k druhu Helminhopsis Heer, 1877, který má stratigrafické rozpětí od kambria po recent (Wetzel 1983a, 1983b).

Výskyt: Opatovice, Dědice, Vranovice, Pístovice, Hamiltony, Nemojany.

Ichnorod Chondrites Sternberg, 1833

Chondrites cf. intricatus (Brongniart, 1823) 


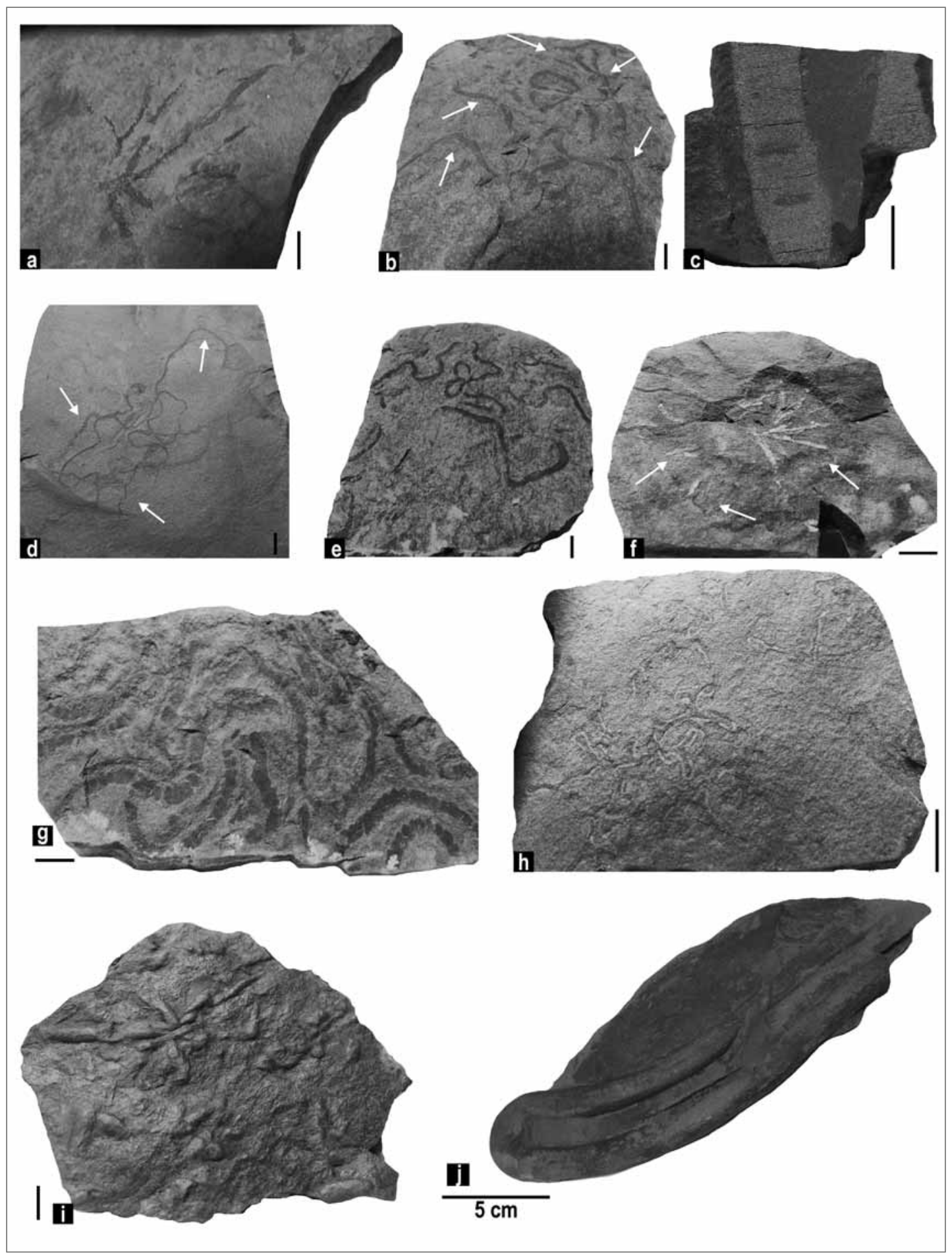

Obr. 2: Vybrané exempláře fosilních stop ze sbírky V. Langa: a) ?Alcyonidiopsis isp., i. č. 11239-1, Opatovice 6, část větvící se stopy; b) Cosmorhaphe isp., i. č. 6273, Opatovice 2, části meandrů stopy; c) Diplocraterion parallelum, i. č. 1929, Opatovice 4, laterální pohled (nábrus) střední ćásti stopy; d) Dictyodora liebeana, i. č. 10662-1, Pístovice Ž, horizontální řez svrchní částí stopy, nepravidelně meandrující průběh stopy; e) Gordia isp., i. č. 6272, Opatovice 2, smyčkovité vinutí stopy; f) Chondrites cf. intricatus, i. č. 4664, Opatovice 10, př́mé větvení stopy; g) Nereites missouriensis, i. č. 13913, Opatovice 2, meandrující vinutí stopy; h) Phycosiphon incertum, i. č. 17274, Lhota 1, detail jednotlivých laloků, i) Planolites beverleyensis, vzorek bez i. č., Dědice K; j) Rhizocorallium isp., i. č. 5091, Pístovice Š, zachovaná prachovcová výplň stopy s patrnou subhorizontální orientací a bazální částí. Grafické měřítko $=1 \mathrm{~cm}(\mathrm{a}-\mathrm{i})$. Fig. 2: Selected specimens of trace fossils from the collection of V. Lang: a) ?Alcyonidiopsis isp., i. n. 11239-1, Opatovice 6, part of branchig trace; b) Cosmorhaphe isp., i. n. 6273, Opatovice 2, part of trace meanders; c) Diplocraterion parallelum, i. n. 1929, Opatovice 4, lateral view of middle part of a trace; d) Dictyodora liebeana, i. n. 10662-1, Pístovice Ž, horizontal cut of upper part of trace, irregularly meandering pattern of trace; e) Gordia isp., i. n. 6272, Opatovice 2, looping pattern of trace; f) Chondrites cf. intricatus, i. n. 4664, Opatovice 10, narrow branching of trace; g) Nereites missouriensis, i. n. 13913, Opatovice 2, meandering pattern of trace; h) Phycosiphon incertum, i. n. 17274, Lhota 1, detail of individual lobes; i) Planolites beverleyensis, specimen without i. n., Dědice K; j) Rhizocorallium isp., i. n. 5091, Pístovice Š, preserved siltstone fill of the trace with subhorizontal orientation and preserved basal part. Graphic scale $=1 \mathrm{~cm}(\mathrm{a}-\mathrm{i})$. 
Obr. 2f.

Materiál: 4 exempláře.

Popis: Endichniální, subhorizontální větvené stopy. Chodby jsou bezstrukturní. Způsob větvení je jednoduchý, průřezy jednotlivých chodeb jsou spíše kruhovité. Jednotlivé tunely jsou vyplněny jemnozrnným jílovým kontrastním materiálem. V příčném řezu se stopa může jevit jako shluky malých, kruhovitých až eliptických bodů, jejichž průměr je srovnatelný s šířkou tunelů, která je v závislosti na exempláři 0,6-2,0 mm.

Poznámky: Ichnorod revidovala Fu (1991), která vyčlenila pouze čtyři ichnodruhy (Chondrites intricatus, Ch. targionii, Ch. patulus a Ch. recurvus). Ovšem ne všechny exempláře mohou být s těmito druhy ztotožněny. Studovaný materiál se nejvíce přibližuje druhu Chondrites intricatus, materiál V. Langa však vykazuje určité odlišnosti, jako např. distenzní rozměr tunelů, který dosahuje i více než $2 \mathrm{~mm}$. Organizmy způsobující tuto stopu byly patrně schopny žít v aerobním i anoxickém prostředí jako chemosymbionti (Fu 1991).

Výskyt: Opatovice 10, Nemojany Ch.

\section{Chondrites isp.}

Materiál: 19 exemplářů.

Popis: Větvené stopy se subparalelní až kolmou orientací vůči vrstevnatosti. Endichniální stopy vykazují složitější typ větvení druhého až třetího řádu. Chodby jsou bezstrukturní s mírně zdrsnělým povrchem.

Výskyt: Hamiltony 1, Opatovice 4, Opatovice 10, Nemojany Ch, Nemojany I, Nemojany H.

Ichnorod Nereites Macleay, 1839

Nereites missouriensis (Weller, 1899)

Obr. $2 \mathrm{~g}$.

Materiál: 32 exemplářů.

Popis: Horizontální, nepravidelně zakřivená, mírně meandrující stopa často ve tvaru položeného písmene J, nebo asymetrických spirálních forem. Stopy jsou tvořeny stužkovitými, oddělenými či meniskujícími mediálními částmi s laločnatými okraji. Přetisky listů však nejsou na dostupném materiálu patrné či jsou velmi špatně zachovány. Šŕrka stopy se pohybuje od 1,5 do 5,5 mm.

Poznámky: Jsou známy četné varianty této stopy, včetně těch, které zachovávají pouze mediální, menisky vyplněnou pásku. Nereites missouriensis je eurybatická stopa známá především z flyšových formací od svrchního prekambria po miocén. Detailní synonymika ichnorodu Nereites je uvedena v práci Uchmana (1995). tovice.

Výskyt: Hamiltony, Dědice, Lhota, Opatovice, Pís-

Nereites isp.

Materiál: 22 exemplářů.

Popis: Stopa je obvykle nepravidelně meandrující. Materiál z myslejovického souvrství nevykazuje detailnější stavbu, stopy jsou bez mediální rýhy.

Poznámky: Původci stop byli pravděpodobně červi požírající substrát, zanechávající za sebou fekální pásku, zachovanou jako mediální tunel. Materiál zde označený jako Nereites isp. je povětšinou nekompletní či špatně zachovalý.

Výskyt: Dědice K, Kobylničky, Nemojany H, Nemojany I, Opatovice 2, Pístovice K, Pístovice Š, Pístovice ŽII.

Ichnorod Phycosiphon Fischer-Ooster, 1858

Phycosiphon incertum Fischer-Ooster, 1858

Obr. 2h.

Materiál: 5 exemplářù.

Popis: Poměrně drobné, úzké a nepravidelně se stáčející trubičky. Na dostupném materiálu bez patrných struktur typu spreite. Povětšinou paralelní s vrstevnatostí. Mohou sestávat i z trubic tvaru písmene U rozvětvujících se v laločnatý systém. Šŕrka stopy je 1-1,2 mm.

Poznámky: Tento ichnodruh reprezentuje činnost eurybatických, oportunistických požíračů sedimentu. Stopa se může objevovat $\mathrm{v}$ různých subtrátech, od jílovo-prachových po jemnozrnné písky. Výskyt je doložen od pobřeží a podle Wetzela a Bromleyho (1994) až po batyál, patrně i abysál. Stratigrafické rozpětí je ordovik-recent. Výskyt: Lhota 1.

Ichnorod Planolites Nicholson, 1873

Planolites beverleyensis (Billings, 1862)

Obr. 2 i.

Materiál: 4 exempláře.

Popis: Horizontální, nerozvětvené válcovité stopy, většinou př́mé nebo mírně zakřivené, méně často nepravidelně zakřivené. $\mathrm{V}$ průřezu mohou být kruhovité nebo eliptické. Povrch stop je bezstrukturní, relativně hladký. Jejich transverzální śírka se pohybuje v intervalu 3-5 mm. Převládající zachování je pozitivní epireliéf a hyporeliéf. Výlitky jsou bezstrukturní, vyplněné stejným materiálem jako okolní sediment, barva a výplň zřídka kontrastuje s okolní horninou. Výztuž stěny není patrná.

Poznámky: Eurybatická stopa. Stratigrafické rozpětí je od sp. proterozoika po recent (Pemberton a Frey 1982; Wetzel 2010).

Výskyt: Dědice K, Opatovice 2.

\section{Planolites isp.}

Materiál: 8 exemplářu z kolekce V. Langa.

Popis: Chodby jsou rovné až mírně zahnuté, méně často lehce zvlněné, nevětvené. Povrch stop je bezstrukturní, mají konvexní epireliéf. Výplň stop tvoří přepracovaný okolní sediment, v některých případech mírně zrnitější.

Výskyt: Dědice K, Opatovice 2, Opatovice 3.

\section{Ichnorod Rhizocorallium Zenker, 1836}

Rhizocorallium isp.

Obr. 2 j.

Materiál: 25 exemplářů.

Popis: Trubicovité stopy víceméně tvaru písmene U, orientovány vzhledem $\mathrm{k}$ vrstevním plochám kose nebo subhorizontálně, s náznaky spreiten struktur. Stěny trubic jsou vyztuženy, ústí je jednoduché. Variabilita ramen je různorodá, ramena mohou být konvergentní i divergentní, spirálně stáčená či s prudkými změnami orientace (úklonu) ramen. Výplň stop je analogická s ichnodruhem 
Diplocraterion parallelum, tedy přepracovaná jemnozrnná droba až prachovec.

Poznámky: Stopy tohoto ichnorodu jsou méně časté než trubicovité stopy ichnodruhu $D i$ plocraterion parallelum, vyskytují se často společně.

Výskyt: Habrovany, Ježkovice $R$, Nemojany Blatnická Dolina, Nemojany H, Opatovice 9, Pístovice Š.

\section{Asociace fosilních stop}

Rozšíření ichnofosilií v kulmu jv. části Drahanské vrchoviny poukazuje na určité rozdíly. Velmi diverzifikovanou ichnocenózu představují lokality Opatovice 2, 3 a 4 . Na těchto lokalitách byly $\mathrm{v}$ hojném počtu nalezeny ichnodruhy Cosmorhaphe isp., Gordia isp., Dictyodora liebeana, Diplocraterion parallelum, Nereites missouriensis a Nereites isp. Za spíše sporadický lze označit výskyt Planolites beverleyensis a Planolites isp., přičemž Rhizocorallium isp. je z této ichnocenózy zastoupen pouze na lokalitě Opatovice 4. Další rozvinutou ichnocenózu představují lokality Pístovice Š, Pístovice $\check{S}$ 1, Pístovice K a Pístovice Ž, na kterých je rovněž přítomna asociace stop s Comorhaphe isp., Gordia isp., Dictyodora liebeana, Diplocraterion paralellum, $\mathrm{Ne}$ reites missouriensis, Nereites isp. a Rhizocorallium isp. Unifikovaná společenstva $\mathrm{v}$ myslejovickém souvrství vytvářejí především ichnodruhy Diplocraterion pararellum a Rhizocorallium isp. a na druhé straně Nereites missouriensis a Cosmoraphe isp., přičemž doprovodný prvek u obou tvoří Dictyodora liebeana.

Stratigraficky je možno v porovnání s existující goniatitovou zonací lokalit (podle Kumpery a Langa 1975) sledovat zřejmou tendenci vývoje od druhově chudých k pestrým společenstvům (tab. 1). Na základě výše jmenovaných asociací a zejména přítomnosti grafoglyptidních stop Cosmorhaphe isp., Gordia isp., Dictyodora liebeana a Nereites missouriensis lze v prostředí myslejovického souvrství indikovat nereitovou ichnofacii. Společenstva stop lze rozdělit na predepoziční kolonizátory (Dictyodora, Cosmorhaphe a Nereites), kteř́i osidlovali dno v období, kdy nedocházelo periodicky $\mathrm{k}$ turbiditnímu př́sunu materiálu. Stopy Diplocraterion isp., Rhizocorallium isp., Planolites isp. a ?Alcyonidiopsis isp. představují postdepoziční spo- lečenstva organizmů, které kolonizovaly substráty dna po eventové sedimentaci turbiditních proudů, ale původně se vyskytovali v proximálnějším prostředí turbiditního systému.

\section{Diskuze}

Obecně jsou v moravskoslezské kulmské pánvi rozšířeny v zóně Goa zoofyková ichnofacie, v zóně Go $\beta$ zoofyková ichnofacie (obohacená o prvky nereitové ichnofacie) a v zóně Go $\gamma$ pak nereitová ichnofacie (Pek a Zapletal 1990; Zapletal a Pek 1999). Oproti sedimentům Nízkého Jeseníku na Drahanské vrchovině zcela chybí sítovité stopy Paleodictyon, Protopaleodictyon či spirální stopy ichnorodu Spirodesmos. Sedimentologické a ichnologické poměry by mohly naznačovat i na rozvinutí zoofykové ichnofacie, avšak v sedimentech myslejovického souvrství zcela chybí signifikantní stopy ichnorodu Zoophycos. Ve většině 
př́ípadů rovněž chybí pro tuto ichnofacii charakteristická asociace ichnorodů Chondrites a Phycosiphon. Z etologického hlediska se na lokalitách myslejovického souvrství nejvíce vyskytují pascichnia. Obytné struktury reprezentují především ichnorody Diplocraterion a Rhizocorallium. Vzácným př́íladem orientovaného využívání substrátu představují stopy po vyžírání sedimentu v podobě stop typu Planolites isp. a ?Alcyonidiopsis isp. (fodinichnia). Stopy Chondrites isp. jsou jediným případem chemichnií. V oblasti rhenohercynika lze srovnávat asociace fosilních stop především z Rýnského břidličného pohoří (Benton 1982), Harzu (Pfeiffer 1969; Stepanek a Geyer 1989), Polska (Muszer a Uglik 2013) ale zejména s oblastí Nízkého Jeseníku (Pek a Zapletal 1990). Ichnospolečenstva z lokalit v myslejovickém souvrství pobliž Vyškova jsou méně diverzifikována než ostatní srovnatelná společenstva kulmského vývoje. Oproti Nízkému Jeseníku jsou sedimenty myslejovického souvrství Drahanské vrchoviny ochuzeny o četné ichnodruhy, které jsou ve středoevropském kulmském prostoru celkem běžné.

\section{Závěr}

Celkem bylo ve sbírce V. Langa uložené v depozitáři Vlastivědného muzea v Olomouci popsáno, zdokumentováno a redefinováno 615 exemplářu v 10 ichnorodech a 13 ichnodruzích. Ve společenstvech stop se běžně vyskytují grafoglyptidní stopy (Dictyodora a Cosmorhaphe), které jsou hlavní indicií pro určení nereitové ichnofacie. Nereitová ichnofacie je obecně vázána na prostředí periodicky ovlivňované pulsním přísunem materiálu, což souhlasí se sedimentologickou analýzou v př́padě myslejovického souvrství. Méně stabilní společenstvo je reprezentováno ichnodruhy Diplocraterion isp., Rhizocorallium isp., Planolites isp., ?Alcynidiopsis isp. a Cosmorhaphe isp. Jelikož je ve sbírce V. Langa zastoupení pre a postdepozičních stop poměrně vyrovnané lze stanovit toto společenstvo jako ichnofacii nereitovou, která byla v určitých fázích osidlována přistěhovalci z proximálních částí turbiditního systému. Druhově nejrozmanitěji se jeví lokality Opatovice 4, Pístovice Š a Pístovice Š1. V Nízkém Jeseníku jsou prrítomny stopy, které více korespondují s ostatními částmi kulmské pánve ve středoevropském prostoru, ty však na Drahanské vrchovině chybějí. V tomto ohledu se zdá být tato část kulmské pánve poněkud netypická.

\section{Literatura}

Benton, M. J. (1982): Dictyodora and associated trace fossils from the Paleozoic of Thuringia. - Lethaia, 15, 115-132.

Billings, E. (1862): New species of fossils from different parts of the lower, Middle and Upper Silurian rocks of Canada. - In: Dawson Brothers (ed.): Palaeozoic Fossils, Volume 1 (1861-1865), 96-168. Geological Survey of Canada.

Brongniart, A. T. (1823): Observations sur les Fucoids. - Sociéte d'Historie Naturelle de Paris, Mémoire, 1, 301-320.

Dvořák, J. (1966): Zpráva o řešení stratigrafie spodního karbonu v kulmském vývoji na Drahanské vrchovině. - Zprávy o geologických výzkumech v r. 1964, Ústřední ústav geologický, 182-185.

Ekdale, A. A. - Berger, W. H. (1978): Deep-sea ichnofacies: modern organism traces on and in pelagic carbonates of the western equatorial Pacific. - Palaegeography, Palaeoclimatology, Palaeoecology, 23, 268-278.

Emmons, E. (1844): The Taconic System based on observation on New York, Massachusetts, Maine, Vermont, and Rhode-Island. - 65 s., Caroll and Cook, Albany.

Fillion, D. - Pickerill, R. K. (1990): Ichnology of the Upper Cambrian? to Lower Ordovician Bell Island and Wabana groups of eastern Newfoundland, Canada. - Palaentographica Canadiana, 7, 1-119.

Fischer-Ooster, C. (1858): Die fossilen Fucoiden der Schweizer Alpen, nebst Erörterungen über deren geologisches Alter. - 130s., Huber, Bern. 
Fu, S. (1991): Funktion, Verhalten und Einteilung fucoider und lophoctenoider Lebensspuren. -Courier Forschungs-Institut Senckenberg, 135, 1-79.

Fuchs, T. (1895): Studien über Fucoiden und Hieroglyphen und Fucoiden. - Sitzungsberichte der mathematisch-naturwissenschaftlichen Klasse der kaiserlichen Akademie der Wissenschaften, 104, 7-12.

Fürsich, F. T. (1974): On Diplocraterion TORELL 1870 and the significance of morphological features in vertical, spreiten-bearing, U-shaped trace fossils. - Journal of Paleontology, 48, 952-954.

Gaigalas, A. - Uchman, A. (2004): Trace fossils from Upper Pleistocene varved clays S of Kaunas, Lithuania. - Geologija, Sedimentologija, 45, 16-26.

Geinitz, H. B. (1867): Über Dictyophyton ?Liebeanum Gein. aus dem Culmschiefer vom Heersberge zwischen Gera und Weyda. - Neues Jahrbuch für Mineralogie, Geologie und Paläontologie, 3, 286-288.

Häntzschel, W. (1975): Trace fossils and problematica. - In: Teichert, C. (ed.): Treatise on Invertebrate Paleontology, part W, Miscellanea, Supplement I, 1-269, Geological Society of America and University of Kansas Press.

Heer, O. (1877): Flora Fossilis Helvetiae. - 182 s., Vorweltliche Flora der Schweiz, Zürich.

Chamberlain, C. K. (1977): Ordovician and Devonian Trace Fossils from Nevada. - 28 s., Nevada Bureau of Mines \& Geology, Reno.

Kumpera, O. - Lang, V. (1975): Goniatitová fauna v kulmu Drahanské vysočiny (moravskoslezská zóna Českého masivu). - Časopis Slezského muzea, Vědy př́rodovědné, 24, 11-32.

Lang, V. (1973): Zkameněliny v kulmských břidlicích jihovýchodní části Drahanské vrchoviny. - 22s., Muzeum Vyškovska. Vyškov.

Lang, V. - Pek, I. - Zapletal, J. (1979): Ichnofosilie kulmu jihovýchodní části Drahanské vrchoviny. - Acta Universitatis Palackianae Olomucensis, Facultas Rerum Naturalium, Geographica-Geologica, 18, 57-96.

MacLeay, W. S. (1839): Note on the Annelida. - In: Murchison, R. I. (ed.): The Silurian System, part II, Organic remains, 699-701, J. Murray.

Massalongo, A. (1856): Studi Paleontologici. - 53 s., Antonelli, Verona.

Mikuláš, R. - Lehotský, T. - Bábek, O. (2004): Trace fossils of the Moravice Formation from the southern Nízký Jeseník Mts. (Lower Carboniferous, Culm facies; Moravia, Czech Republic). - Bulletin of Geosciences, 79, 2, 81-98.

Muszer, J. - Uglik, M. (2013): Palaeoenvironmental reconstruction of the Upper Visean Paprotnia Beds (Bardo Unit, Polish Sudetes) using ichnological and palaeontological data. - Geological Quarterly, 57, 3, 365-384.

Nicholson, H. A. (1873): Contributions to the study of the errant annelids of the older Palaeozoic rock. - Proceedings of the Royal Society of London, 21, 288-290.

Pek, I. - Zapletal, J. (1990): The importance of ichnology in geologic studies of the eastern Bohemian Massif (Lower Carboniferous), Czechoslovakia. - Ichnos: An International Journal for Plant and Animal Traces, 1, 174-149.

Pemberton, S. G. - Frey, R. W. (1982): Trace fossil nomenclature and the Planolites - Palaeophycus dilemna. - Journal of Paleontology, 56, 4, 843-881.

Pfeiffer, H. (1969): Die Spurenfossilien des Kulms (Dinants) und Devons der Frankenwälder Querzone (Thüringen). - Jahrbuch für Geologie und Paläontologie, 2, 651-717.

Pickerill, R. K. - Peel, J. S. (1991): Trace fossils from the Lower Cambrian Bastion Formation of North-East Greenland. - Grønlands Geologiske Undersøgelse, Rapport, 147, 5-43.

Rothpletz, A. (1896): Über die Flysch-Fucoiden und einige andere fossile Algen sowie über liassische, Diatomeen-führende Hornschwämme. - Zeitschrift der Deutschen Geologischen Gesselschaft, 48, 854-914.

Seilacher, A. (1992): Quo vadis ichnology? - In: Maples C. G. - West R. R. (ed.): Trace fossils, 224-238, Short Courses in Paleontology, Knoxville.

Stepanek, J. - Geyer, G. (1989): Spurenfosilien aus dem Kulm (Unterkarbon) des Frankenwaldes. Beringeria 1, 1-55.

Sternberg, K. G. (1833): Versuch einer geognostisch-botanischen Darstellung der Flora der Vorwelt. IV Heft. - 48 s., C. E. Brenck, Regensburg.

Torell, O. M. (1870): Petrifacta Suecana Formationis Cambricae Lunds Universitet. - Tidskrift, 6, 1-14.

Uchman, A. (1995): Taxonomy and paleoecology of flysch trace fossils: The Marnoso-Arenacea Formation and associated facies (Northern Appenines, Italy). - Beringeria, 15, 3-115.

Uchman, A. (1998): Taxonomy and ethology of flysch Trace fossils: revision of the Marian Książkiewicz collection and studies of complementary material. - Annales Societatis Geologorum Poloniae, 68, 105-218.

Weiss, E. (1884): Beitrag zur Culm-Flora von Thüringen. - Jahrbuch für Geologie Landesanst, 4, 81-100.

Weller, S. (1899): Kiderhook faunal studies. I. The fauna of the vermicular sandstone at Northview, Webster County, Missouri. Trans. - Academie of Sciences St. Louis, 9, 9-51.

Wetzel, A. (1983a): Biogenic structures in modern slope to deep-sea sediments in the Sulu Sea Basin (Philippines). - Palaeogeography, Palaeoclimatology, Palaeoecology, 42, 285-304.

Wetzel, A. (1983b): Biogenic sedimentary structures in a modern upwelling region: northwest African continental margin. In: Thiede, J. - Suess, E. (ed.): Coastal upwelling and its sediments, Record of ancient coastal upwelling, 123-144.

Wetzel, A. (2010): Deep-sea ichnology: Observations in modern sediments to interpret fossil counterparts. - Acta Geologica Polonica, 60, 1, 125-138.

Wetzel, A. - Bromley, R. G. (1994): Phycosiphon incertum revisited: Anconichnus horizontalis is its junior subjetive synonym. Journal of Paleontology, 68, 6, 1396-1402.

Zapletal, J. - Pek, I. (1999): Ichnofacies of the Lower Carboniferous in the Jeseník Culm (Moravo-Silesian Region, Bohemian Massif, Czech Republic). - Bulletin of the Czech Geological Survey, 74, 3, 343-346.

Zenker, J. C. (1836): Historisch-topografisches Taschenbuch von Jena und seiner Umgebung besonders in seiner naturwissenschaftlicher und medicinischer Beziehung. - 339 s., J. C. Zenker, Jena.

Zita, F. (1963): Přehled dosavadních nálezů kulmské fauny a flóry na Drahanské vrchovině a jejich stratigrafický význam. - Acta Universitatis Palackianae Olomucensis, Facultas Rerum naturalium, 10, 193-207. 